\title{
Activation of Caspase-3 in HL-60 Cells Treated with Pyrithione and Zinc
}

\author{
Masuo Kondoh, ${ }^{a}$ Emi Tasaki, ${ }^{b}$ Masufumi Takiguchi, ${ }^{b}$ Minoru Higashimoto, ${ }^{b}$ \\ Yoshiteru Watanabe, ${ }^{a}$ and Masao SATO ${ }^{*, b}$ \\ ${ }^{a}$ Department of Pharmaceutics and Biopharmaceutics, Showa Pharmaceutical University; Machida, Tokyo 194-8543, \\ Japan: and ${ }^{b}$ Faculty of Pharmaceutical Sciences, Tokushima Bunri University; Tokushima 770-8514, Japan. \\ Received November 19, 2004; accepted January 5, 2005
}

\begin{abstract}
The transition metal zinc ( $\mathrm{Zn})$ is an endogenous regulator of apoptosis. The ability of $\mathrm{Zn}$ to modulate apoptosis is believed to be mediated by the regulation of caspase activity. Previously, we reported that an acute influx of labile $\mathrm{Zn}$ induced apoptosis via activation of caspase in human leukemia HL-60 cells treated with a $\mathrm{Zn}$ ionophore (Py, pyrithione) and $\mathrm{Zn}$ at 1 and $25 \mu \mathrm{M}$, respectively. In the present study, we investigated the involvement of caspase-3 in Py $(1 \mu \mathrm{M}) / \mathrm{Zn}(25 \mu \mathrm{M})$-induced apoptosis in HL-60 cells. Pro-caspase-3 is an inactive form of caspase-3. The processing of pro-caspase-3, a sign of caspase-3 activation, occurred $6 \mathrm{~h}$ after treatment with Py/Zn. Proteolysis of poly (ADP-ribose) polymerase (PARP), a substrate of caspase-3, was also observed $6 \mathrm{~h}$ after treatment with Py/Zn. We also confirmed the elevation of caspase-3 activity as an index of the cleavage of amino acid sequences recognized by activated caspase-3. An inhibitor of caspase-3 attenuated the appearance of the DNA ladder. Taken together, these results indicate that the activation of caspase-3 is partly responsible for the induction of apoptosis in Py/Zn-treated HL-60 cells.
\end{abstract}

Key words zinc; caspase-3; apoptosis; HL-60 cell

The effect of zinc ( $\mathrm{Zn})$ on apoptosis is of great interest and has been studied in in vitro and in vivo experimental models. ${ }^{1,2)} \mathrm{Zn}$ has both pro-apoptotic effects and anti-apoptotic effects. While $\mathrm{Zn}$ attenuated the induction of apoptosis by glucocorticoid at $0.5-5.0 \mathrm{~mm},{ }^{3)} \mathrm{Zn}$ induced apoptosis at $80-200 \mu \mathrm{M}^{4)}$ in mouse thymocytes. On the contrary, Zn at concentrations of 10 to $50 \mu \mathrm{M}$ attenuated manganese-induced apoptosis, but higher concentrations of $\mathrm{Zn}(50-100 \mu \mathrm{M})$ increased cell death in human Burkitt lymphoma B cells. ${ }^{5} \mathrm{Zn}$ had no effect on interleukin-3-mediated apoptosis in murine B lymphoid cells but enhanced CD95-mediated apoptosis in human T lymphoid cells. ${ }^{6}$ Thus, $\mathrm{Zn}$ has opposite effects on the induction of apoptosis, but the mechanism by which $\mathrm{Zn}$ affects apoptosis remains unclear.

Caspases are a conserved family of cysteine proteases that play pivotal roles in apoptosis. ${ }^{7)}$ Caspases are present as proenzymes that are readily cleaved and activated during apoptosis, providing the cell with a means to rapidly amplify its apoptotic response. ${ }^{8)}$ Three fundamental caspase-activating pathways in mammalian cell apoptosis have been identified: (1) a pathway in which mitochondrial functional integrity is altered, (2) a pathway in which extracellular death receptors are coupled to cytoplasmic death domains, and (3) a pathway in which caspase is activated in the endoplasmic reticulum. ${ }^{9-11)}$ Regardless of the apoptotic-activating pathway, caspase-3 appears to be the point of intersection for caspase-mediated cell death leading to the conserved apoptotic morphology. As a primary executor caspase, caspase-3 is responsible for many of the death foci related to apoptosis, including the induction of DNA damage and poly (ADP-ribose) polymerase (PARP) cleavage. ${ }^{12,13)}$

The effect of $\mathrm{Zn}$ on apoptosis induction has been mainly investigated in cells treated with apoptotic stimuli, including some antitumor agents and geranylgeraniol. Inhibitory effects of $\mathrm{Zn}$ on the induction of apoptosis were observed with inhibition of apoptotic stimuli-mediated activation of caspase-3. ${ }^{14-16)}$

Previously, we found that an influx of $\mathrm{Zn}$ into the cell, which was mediated by a $\mathrm{Zn}$ ionophore (Py, pyrithione) and $\mathrm{Zn}$, induced apoptosis via activation of caspases in human leukemia HL-60 cells. ${ }^{17)}$ Although a broad-spectrum inhibitor of caspases attenuated $\mathrm{Py} / \mathrm{Zn}$-induced apoptosis, the involvement of caspase-3 in Py/Zn-induced apoptosis is obscure. In the present study, we investigated the activation of caspase- 3 in Py/Zn-treated cells and estimated the involvement of caspase-3 in Py/Zn-induced apoptosis.

\section{MATERIALS AND METHODS}

Materials Zinc sulfate and sodium pyrithione (Py) were purchased from Sigma (St Louis, MO, U.S.A.). Zinc sulfate $(10 \mathrm{~mm})$ and Py $(100 \mu \mathrm{M})$ were dissolved in sterile water, and were stored at $-20^{\circ} \mathrm{C}$ before use. Z-DEVD-fmk, an inhibitor of caspase-3, was obtained from Calbiochem-Novabiochem (San Diego, CA, U.S.A.) and dissolved in EtOH at $20 \mathrm{~mm}$. Volume of vehicle used in this experiment did not exceed $1 \%$ of the culture medium.

Cell Culture HL-60 cells (human promyelocytic leukemia cells) were cultured in RPMI 1640 containing $10 \%$ fetal bovine serum, and maintained in a $5 \% \mathrm{CO}_{2}$ humidified atmosphere at $37^{\circ} \mathrm{C}$.

DNA Fragmentation Assay DNA ladder formation was analyzed as described previously. ${ }^{18)}$ Briefly, Cells were incubated in the lysis buffer containing $10 \mathrm{~mm}$ Tris- $\mathrm{HCl}(\mathrm{pH} 8.0)$, $10 \mathrm{~mm}$ EDTA, $0.5 \%(\mathrm{w} / \mathrm{v})$ SDS and $0.1 \%(\mathrm{w} / \mathrm{v})$ RNase A for $60 \mathrm{~min}$ at $50^{\circ} \mathrm{C}$. Phenol/chloroform-extracted DNA was subjected to a $1.8 \%$ agarose gel electrophoresis and stained with ethidium bromide.

Western Blot Analysis Cells were lysed in the lysis buffer [1\% Nonidet P-40, $20 \mathrm{~mm}$ Tris- $\mathrm{HCl}$ (pH 8.0), $137 \mathrm{~mm}$ $\mathrm{NaCl}, 10 \%$ glycerol, $1 \mathrm{~mm}$ phenylmethylsulfonylfluoride and $1 \mathrm{~mm}$ EDTA] by sonication. Equal amounts of samples were subjected to SDS-polyacrylamide gel electrophoresis and then transferred to polyvinylidene difluoride membranes (Millipore Co. Ltd., Bedford, MA, U.S.A.). The membrane was blocked with $10 \mathrm{~mm}$ Tris- $\mathrm{HCl}(\mathrm{pH} 7.5), 100 \mathrm{~mm} \mathrm{NaCl}$ 
and $0.05 \%$ Tween 20 containing 5\% (w/v) nonfat milk, and then the membrane was incubated with anti-PARP Ab (BD PharMingen, San Diego, CA, U.S.A.) or anti-caspase-3 Ab (BD PharMingen) following the incubation with a horseradish peroxide-labeled antibody as a secondary antibody. The bands reacted with the antibody were revealed by ECL-based detection (Amersham Biosciences Inc., Piscataway, NJ, U.S.A.).

Caspase Assay Activity of caspase-3 was quantified using caspase colorimetric assay kit according to the manufacturer's protocol (MBL, Nagoya, Japan).

Statistical Analysis Data were analyzed by Student's $t$ test. The acceptable level of significance was set at $p<0.05$.

\section{RESULTS}

We previously reported that the treatment of HL-60 cells with Py $(1 \mu \mathrm{M})$ plus $\mathrm{Zn}(25 \mu \mathrm{M})$ resulted in DNA fragmentation, a typical feature of apoptotic cells, and we found that a broad-spectrum inhibitor of caspase attenuated Py/Zn-induced apoptosis. ${ }^{16)}$ To confirm the activation of caspase-3 during apoptosis induced by Py $(1 \mu \mathrm{M})$ plus $\mathrm{Zn}(25 \mu \mathrm{M})$ in HL-60 cells, we examined caspase-3 activity in $\mathrm{Py} / \mathrm{Zn}$ treated cells. As shown in Fig. 1, the activity of caspase-3 was elevated by treatment with $\mathrm{Py} / \mathrm{Zn}$. Caspase- 3 is present as an inactive $32 \mathrm{kDa}$ precursor and is activated upon cleavage by an upstream caspase, which yields subunits of 17 and $19 \mathrm{kDa}$, following proteolysis of PARP. ${ }^{18,19)} \mathrm{Next}$, we investigated the processing of caspase- 3 and PARP proteolysis in Py/Zn-treated HL-60 cells. The cleavage of caspase- 3 into 17 and $19 \mathrm{kDa}$ fragments occurred $6 \mathrm{~h}$ after Py/Zn-treatment (Fig. 2A). PARP proteolysis was also observed $6 \mathrm{~h}$ after treatment with $\mathrm{Py} / \mathrm{Zn}$, which paralleled the appearance of DNA fragmentation (Figs. 2B, C). These data indicate that the activation of caspase- 3 may be responsible for the induction of apoptosis in Py/Zn-treated HL-60 cells. Finally, to clarify the involvement of caspase- 3 in Py/Zn-induced apoptosis, we investigated whether an inhibitor of caspase-3, Z-DEVD-fmk, inhibited apoptosis induced by $\mathrm{Py} / \mathrm{Zn}$ treatment. As shown in Fig. 3, Z-DEVD-fmk attenuated DNA fragmentation induced by $\mathrm{Py} / \mathrm{Zn}$. Taken together, these results indicate that $\mathrm{Py} / \mathrm{Zn}$ induces apoptosis through a caspase-3-dependent pathway.

\section{DISCUSSION}

We previously found that an acute increase in the intracel-

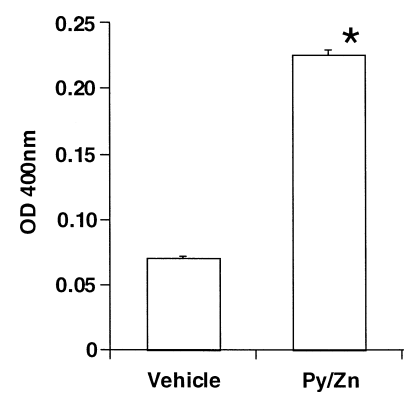

Fig. 1. Caspase-3 Activity in Py/Zn-Treated HL-60 Cells

HL-60 cells were treated with Py $(1 \mu \mathrm{M})$ and $\mathrm{Zn}(25 \mu \mathrm{M})$ for $6 \mathrm{~h}$. Then, caspase- 3 activity was determined as described in Materials and Methods. Data are means \pm S.D. $(n=4)$. $*$ Significant difference from the vehicle-treated cells $(p<0.05)$. Data are representative of three independent experiments. lular $\mathrm{Zn}$ level using a $\mathrm{Zn}$ ionophore, Py, induced apoptosis via a caspase-dependent pathway in HL-60 cells. ${ }^{17}$ In this study, we speculated that this acute increase in $\mathrm{Zn}$ levels may induce apoptosis partly via activation of caspase-3.

$\mathrm{Zn}$ is a familiar inhibitor of caspase-3. In 1997, Perry et al. used recombinant caspase- 3 to show that $\mathrm{Zn}$ directly inhibits caspase-3 in cell-free system. ${ }^{14)}$ Treatment with $\mathrm{Py} / \mathrm{Zn}$ increases the amount of labile $\mathrm{Zn}$ in the cytosol. ${ }^{20,21)}$ Based on these reports, $\mathrm{Py} / \mathrm{Zn}$ seems to increase the amount of intracellular labile $\mathrm{Zn}$ levels followed by inhibition of caspase- 3 activity. However, the treatment of cells with $\mathrm{Py} / \mathrm{Zn}$ stimu-

\section{A. Activation of Caspase-3}

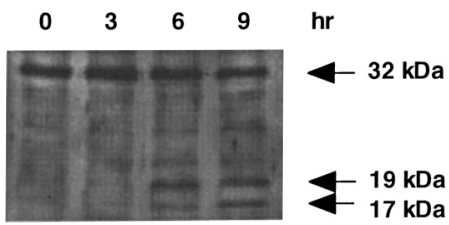

B.

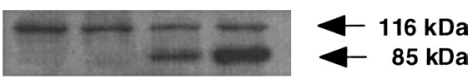

C. DNA fragmentation

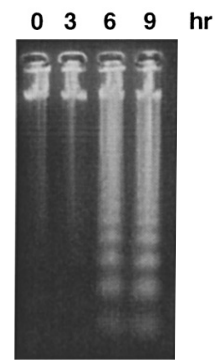

Fig. 2. Time-Course Study of the Processing of Caspase-3

Cell were treated with $\mathrm{Py}(1 \mu \mathrm{M})$ and $\mathrm{Zn}(25 \mu \mathrm{M})$ for the indicated time periods. Then, the cells were harvested, and processing of caspase-3 (A), PARP proteolysis (B) and appearance of DNA (C) were examined as described in Materials and Methods. Data are representative of three independent experiments.

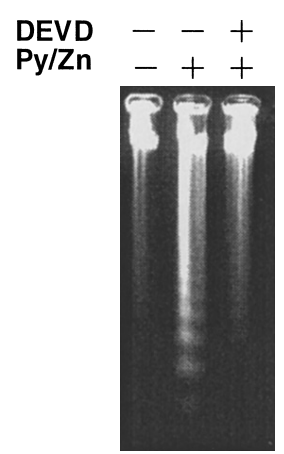

Fig. 3. Effect of DEVD on Py/Zn-Induced Apoptosis in HL-60 Cells

After $3 \mathrm{~h}$ of treatment with DEVD $(100 \mu \mathrm{M})$, the cells were treated with Py $(1 \mu \mathrm{M})$ and $\mathrm{Zn}(25 \mu \mathrm{M})$ for an additional $6 \mathrm{~h}$. Then, the cells were harvested, and a DNA fragmentation assay was performed. Data are representative of three independent experiments 
lated caspase- 3 activity. If the $\mathrm{Py} / \mathrm{Zn}$-induced labile $\mathrm{Zn}$ interacts directly with caspase- 3 , caspase- 3 may remain in an inactive form. One possible explanation is that the labile $\mathrm{Zn}$ may not be associated with activation of caspase-3. Although we did not examine the relationship between intracellular labile $\mathrm{Zn}$ and caspase- 3 activation, a $\mathrm{Zn}$ chelator attenuated $\mathrm{Py} / \mathrm{Zn}$-induced apoptosis and PARP proteolysis, a sign that caspases, including caspase-3, have been activated. ${ }^{16)}$ Moreover, an inhibitor of caspase-3 decreased the appearance of DNA fragmentation (Fig. 3), suggesting that the activation of caspase-3 is at least partly responsible for the induction of apoptosis by Py/Zn in HL-60 cells. Another possible explanation is that the labile $\mathrm{Zn}$ may activate caspase- 3 in an indirect manner. Indeed, we indicated that activation of p38 mitogen-activated protein kinase (p38MAPK) may be located upstream of the activation of caspases in Py/Zn-treated HL-60 cells. ${ }^{17)} \mathrm{SB} 203680$, an inhibitor of p38MAPK, partly decreased caspase- 3 activity in Py/Zn-treated HL-60 cells (Vehicle, OD $400 \mathrm{~nm}=0.070 \pm 0.001 ; \quad P y / Z n \quad O D 400 \mathrm{~nm}=$ $0.225 \pm 0.004 ; \mathrm{Py} / \mathrm{Zn}$ plus SB203580 OD400 $\mathrm{nm}=0.137 \pm$ 0.003 ), suggesting that $\mathrm{Py} / \mathrm{Zn}$ may activate $\mathrm{p} 38 \mathrm{MAPK}$ following activation of caspase-3. Taken together, these results indicate that $\mathrm{Py} / \mathrm{Zn}$-induced apoptosis may be triggered by activation of caspase-3.

This is the first report to indicate that caspase- 3 is activated in Py/Zn-treated HL-60 cells. Although additional research is needed to determine the mechanism of caspase-3 activation, our data provide new insight into the apoptosis-inducing property of Zn.

\section{REFERENCES}

1) Thomas D. J., Caffrey T. C., Toxicology, 68, 327-337 (1991).
2) Matsushita K., Kitagawa K., Matsuyama T., Ohtsuki T., Taguchi A., Mandai K., Mabuchi T., Yagita Y., Yanagihara T., Matsumoto M., Brain Res., 743, 362-365 (1996).

3) Cohen J. J., Duke R. C., J. Immunol., 132, 38-42 (1984).

4) Telford W. G., Fraker P. J., J. Cell Physiol., 164, 259-270 (1995).

5) Schrantz N., Auffredou M. T., Bourgeade M. F., Besnault L., Leca G., Vazquez A., Cell Death Differ., 8, 152-161 (2001).

6) Sutherland L. C., Anderson C. L., Williams G. T., J. Immnuol. Methods, 234, 43-50 (2000).

7) Nicholson D. W., Ali A., Thornberry N. A., Vaillancourt J. P., Ding C. K., Gallant M., Gareau Y., Griffin P. R., Labelle M., Lazebnik Y. A., Munday N. A., Raju S. M., Smulson M. E., Yamin T. T., Yu V. L., Miller D. K., Nature (London), 376, 37-43 (1995).

8) Cohen G. M., Biochem. J., 326, 1-16 (1997).

9) Reed J. C., Cell, 91, 559-562 (1997).

10) Nakagawa T., Zhu H., Morishima N., Li E., Xu J., Yankner B. A., Yuan J., Nature (London), 403, 98-103 (2000).

11) Bitko V., Barik S., J. Cell Biochem., 80, $441-454$ (2001).

12) Kaufmann S. H., Desnoyers S., Ottaviano Y., Davidson N. E., Poirier G. G., Cancer Res., 53, 3976-3985 (1993).

13) Wolf B. B., Schuler M., Echeverri F., Green D. R., J. Biol. Chem., 274, 30651-30656 (1999).

14) Perry D. K., Smyth M. J., Stennicke H. R., Salvesen G. S., Duriez P., Poirier G. G., Hannun Y. A., J. Biol. Chem., 272, 18530-18533 (1997).

15) Wolf C. M., Morana S. J., Eastman A., Cell Death Differ., 4, 125-129 (1997).

16) Aiuchi T., Mihara S., Nakaya M., Masuda Y., Nakajo S., Nakaya K., J. Biochem. (Tokyo), 124, 300-303 (1998).

17) Kondoh M., Tasaki E., Araragi S., Takiguchi M., Higashimoto M., Watanabe Y., Sato M., Eur. J. Biochem., 269, 6204-6211 (2002).

18) Watabe M., Machida K., Osada H., Cancer Res., 60, 5214-5222 (2000).

19) Han Z., Hendrickson E. A., Bremner T. A., Wyche J. H., J. Biol. Chem., 272, 13432-13436 (1997).

20) Thornberry N. A., Lazebnik Y., Science, 281, 1312-1316 (1998).

21) Zalewski P. D., Forbes I. J., Giannakis C., Biochem. Int., 24, 10931101 (1991). 